\title{
Digestion of alfalfa and grass silages in sheep. 1. Rates of fermentation in and passage from the reticulorumen
}

\author{
Marlou W. Bosch ${ }^{1}$, I. M. Janssen ${ }^{1,2}$, J. van Bruchem ${ }^{1}$, H. Boer ${ }^{2}$ and G. Hof ${ }^{2}$ \\ 1 Department of Animal Physiology, Wageningen Agricultural University, Haar- \\ weg 10, NL 6709 PJ Wageningen, Netherlands \\ ${ }^{2}$ Department of Animal Nutrition, Wageningen Agricultural University, Haag- \\ steeg 4, NL 6708 PM Wageningen, Netherlands
}

Received 5 August 1987; accepted 26 February 1988

Key words: feed intake, reticuloruminal degradation, cell wall constituents, cellulose, hemicellulose, lignin, rumination, particle pools

\begin{abstract}
Wilted alfalfa and grass silages were fed to mature wethers. Fractional rate of passage of particles $\left(k_{\mathrm{p}}\right)$ from the reticulorumen, as determined with Chromium-mordanted Neutral Detergent Fibre (Cr-NDF), was related negatively to digestibility, but positively to level of feed intake. Ratio of $k_{\mathrm{p}}$ to $k_{1}$ (liquids) decreased with higher intake of indigestible material. Models were developed to interrelate cell wall pool in the reticulorumen, passage of undegraded cell walls in the proximal duodenum, fractional rate of passage of particles, fractional rate of degradation of cell walls $\left(k_{\mathrm{d}}\right)$, and the proportion of large particles $\left(f_{\mathrm{L}}\right)$ within the total particle pool in the reticulorumen. Although estimates of $k_{\mathrm{d}}$ and $f_{\mathrm{L}}$ were not very accurate yet, differences between silages could be characterized.

The $k_{\mathrm{d}}$ values of cell walls in grass silages were related negatively to stage of maturity at harvesting, $f_{\mathrm{L}}$ however positively. Between grass and alfalfa silages with a comparable $k_{\mathrm{d}}$, the extent at which cell walls left the reticulorumen was highest with alfalfa, as caused by a higher undegradable residue.
\end{abstract}

\section{Introduction}

In the Netherlands, the major part of the roughage supplied to cattle in the winter season consists of silages. Mainly grass-wilted silages are fed. In high-producing dairy cows, energy supply is regarded as the first factor limiting production, because of a limited feed intake capacity. When feeds are supplied with lower digestibilities, intake is reduced. For this reason, nutrient requirement of high-producing dairy cattle can only be met with diets consisting for a substantial part of mixed concentrates. Nevertheless, there are several reasons to consider the roughage part of 
the diets as well. With diets, including a higher roughage proportion, a more stabilized forestomach fermentation is obtained. Relative to mixed concentrates, goodquality roughage also provides nutrients at lower cost.

In high-producing dairy cows, feed intake is presumably limited physically, that means by the capacity of the reticulorumen. As a consequence, feed intake is supposed to be related to both the rate of degradation of the feed in the reticulorumen and the rate of passage of undigested feed particles to the lower gut. The present paper describes the rate of degradation of grass and alfalfa silages in the reticulorumen, as determined in cattle with nylon bags and as computed in sheep based on extent of digestion in and passage of undigested feed particles from the reticulorumen. The latter was determined with $\mathrm{Cr}-\mathrm{NDF}$, as estimated from the faecal excretion curve.

The nutritive value of silages is not only determined by feed intake and extent of digestion, but by the nature of digestion products as well. In this paper, the course of digestion of cellulose, hemicellulose and lignin in the reticulorumen and along the intestines is presented. The degradation of dietary and synthesis of microbial proteins in the rumen, and subsequent digestibility of the protein in the small intestine, were determined as well. These results are reported by van Bruchem et al. (1988).

Extrapolation of results obtained with sheep to dairy cattle is only allowed with great reserve. It should be considered that dairy cattle are fed at a considerably higher level, as compared to mature wethers, fed at maintenance level. Moreover, to high-producing dairy cattle, roughage has to be supplied together with mixed concentrates. Concentrates have a higher rate of digestion and passage from the reticulorumen, and presumably also affect the rate of degradation of the roughage part of the diet through rumen $\mathrm{pH}$.

\section{Materials and methods}

Mature wethers with a live weight of about $75 \mathrm{~kg}$ were fitted with a rumen cannula (polyvinylchloride, $25 \mathrm{~mm}$ i.d.) in the dorsal rumen sac, an infusion tube (silicon rubber, $3 \mathrm{~mm}$ i.d.) in the abomasum and with T-shaped pvc cannulas (12 mm i.d.) in the proximal duodenum and terminal ileum. The sheep had well recovered from surgery before the onset of the experiments. During the experiments the sheep were kept in metabolism cages and were fed 6 equal portions of roughage diets offered over the day. Water was ad libitum.

A three-week adaptation period was followed by a six-week experimental period. Treatments were allocated to sheep according to a latin square block design.

In Exp. 1, four wethers were fed ad libitum a wilted grass silage (G1) and an alfalfa silage (A). In Exp. II, four wethers were fed another grass silage at two levels of intake, ad libitum and $70 \%$ of ad lib, G2H and G2L, respectively.

In the first and the sixth week of the experiments, the turnover rates of the liquid and particulate phase in the reticulorumen were estimated with Co-EDTA (CoEDTA was prepared identically as Cr-EDTA described by Binnerts et al., 1968), 
and Cr-NDF (Uden et al., 1980), respectively. On monday at 8:00 h, $10 \mathrm{~g} \mathrm{Cr}-\mathrm{NDF}$ (ca $5 \% \mathrm{Cr}, 0.2-1 \mathrm{~mm}$ ) and $100 \mathrm{ml} \mathrm{Co-EDTA} \mathrm{(ca} 4.7 \mathrm{~g} \mathrm{Co} / 1)$ were administered in the ventral rumen sac. Co was determined with an atomic absorption spectrophotometer (Perkin Elmer 360) in rumen fluid samples, collected hourly on monday from 11:00 till 18:00 $\mathrm{h}$ and on tuesday from 9:00 till 16:00 h. Faeces were collected from monday 18:00 h till wednesday 20:00 h continuously, and on thursday and friday from 8:00 till 20:00 h. Faeces were dried and $\mathrm{Co}$ and $\mathrm{Cr}$ were measured by atomic absorption after wet destruction at wavelengths of 251.0 and $357.9 \mathrm{~nm}$, respectively. The dilution rate of the liquid phase marker was estimated directly in rumen fluid $\left(k_{l . r}\right)$. From the faecal excretion curves of both markers, the rate constants $k 1$ (reticulorumen) and $k 2$ (second mixing compartment) were deduced according to the equation:

$$
C_{t}=A_{\mathrm{o}}\left[\mathrm{e}^{-k 1(t-\mathrm{TT})}-\mathrm{e}^{-k 2(t-\mathrm{TT})}\right]
$$

The parameters $k 1$ and $k 2$ were estimated as described by Grovum \& Williams (1973), $k 1$ representing fractional passage rate from the reticulorumen, and $k 2$ fractional passage rate from the caecum and colon. Subsequently both parameters were optimized by a BMDP iterative non-linear regression computer program (Anonymous, 1983). In this equation, $C_{t}$ represents marker concentration at time $t$ and TT the digesta transit time. $A_{\mathrm{o}}$ is a constant.

The $\mathrm{pH}$ and the ammonia concentration were measured in samples of rumen fluid taken at 12:00, 13:00, 14:00, 15:00 and 16:00 h. The ammonia concentration was measured by adding phenol and hypochlorite. The extinction of the resulting blue colour was estimated at $623 \mathrm{~nm}$ with a Perkin Elmer 55E spectrophotometer. The average VFA concentrations were determined in a pooled sample (12:00, 13:00, 14:00 and 15:00 h), by gas liquid chromatography (Packard 419, glass column filled with chromosorb 101 , carrier gas saturated with formic acid, $190{ }^{\circ} \mathrm{C}$, isocapronic acid was used as internal standard).

In the third and fourth week of the experiment the passage of the dry matter in the duodenum and in the ileum were measured with a continuous infusion of about $20 \mathrm{~g} / \mathrm{h}$ of Co-EDTA (ca $1.0 \mathrm{~g} \mathrm{Co} /$ ) (Exp. I) or Cr-EDTA (ca $1.0 \mathrm{~g} \mathrm{Cr} / 1)$ (Exp. II) into the abomasum. In the first experiment besides Co-EDTA also Cr-NDF was used. These two markers gave the same results. Because of that it was decided only to use a soluble marker in the second experiment. Hourly samples of approximately $20 \mathrm{~g}$ of duodenal and ileal digesta were taken from monday till thursday from 8:00 till 20:00 h. The samples were freeze-dried, ground $(1 \mathrm{~mm}$ sieve $)$ and pooled per sheep per experimental period and were analysed for dry matter, ash, nitrogen $(\mathrm{N})$, $\mathrm{Co}$ or $\mathrm{Cr}$, amino acids (including diamino pimelic acid (DAPA)), neutral detergent fiber (NDF), acid detergent fiber (ADF) and acid detergent lignin (ADL). Dry matter was determined by drying to constant weight at $101{ }^{\circ} \mathrm{C}$, ash in an oven at $550{ }^{\circ} \mathrm{C}$ and $\mathrm{N}$ by the $\mathrm{Kjeldahl}$ method with $\mathrm{K}_{2} \mathrm{SO}_{4}$ and $\mathrm{HgO}$ as catalysts. Amino acid analyses are described by van Bruchem et al. (1988). NDF, ADF and ADL were measured according to Goering \& van Soest (1970). Hemicellulose was calculated as NDF-ADF, and cellulose as ADF-ADL. Calculations of the digestibility of cell 
wall constituents were based on the amounts passing the small intestine, relative to the quantities ingested.

In weeks 2 and 5, rumen contractions were recorded with an open tip-catheter. Contractions were transformed in electrical signals by a pressure transducer. Specifications were as follows: frequency band $0.01-0.10 \mathrm{~Hz}$, duration pressure peak $>$ $2 \mathrm{sec}$, pressure $>5 \mathrm{~mm} \mathrm{Hg}$.

The rates of degradation $\left(k_{\mathrm{d}}\right)$ of cell walls in the silages fed in Exp. I (A and G1) were determined with nylon bags $(41 \times 41 \mu \mathrm{m})$ in cattle as described in more detail by Kwakkel et al. (1986). Rates of degradation were calculated according to the following model:

$$
f_{1}=f_{\mathrm{R}}+\left(1-f_{\mathrm{S}}-f_{\mathrm{R}}\right) \times \mathrm{e}^{-k} \mathrm{~d}^{\left(t-t^{\prime}\right)}
$$

with $f_{\mathrm{t}}$ representing the residual fraction of cell walls at time $t, f_{\mathrm{S}}$ the soluble fraction, $f_{\mathrm{R}}$ the indigestible fraction, $k_{\mathrm{d}}$ the fractional rate of degradation and $t$, the lag time.

The data were analysed statistically by a two-sampled analysis of variance, taking into account differences between sheep and experimental periods. Experiments I and II were analysed separately. Student $t$ values for testing significances are to be calculated dividing contrasts between diets by SEM $\times \sqrt{2}$ within experiments or by $\sqrt{ }\left(\mathrm{SEM}_{\mathrm{I}}{ }^{2}+\mathrm{SEM}_{\mathrm{II}}{ }^{2}\right)$ between experiments $(\mathrm{d} . \mathrm{f} .=8)$.

\section{Results}

Composition, intake and digestibility of the experimental diets are given in Table 1. Digestibility of the grass silage was higher in Exp. II (G2) than in Exp. I, because of

Table 1. Composition (C. \%), daily intake (I, g) and DM digestibility of alfalfa (A) and grass silages (G1 and G2).

\begin{tabular}{|c|c|c|c|c|c|c|c|}
\hline & \multicolumn{4}{|c|}{ Exp. I } & \multirow{4}{*}{$\frac{\text { Exp. I }}{\frac{G 2}{C} .}$} & \multirow{2}{*}{$\cdots$} & \\
\hline & \multicolumn{2}{|l|}{ A } & \multicolumn{2}{|l|}{$\mathrm{G} 1$} & & & \\
\hline & $\mathrm{C}$ & 1 & $\mathrm{C}$ & I & & I & \\
\hline & & & & & & $\mathrm{G} 2 \mathrm{H}$ & G2L \\
\hline DM & 52.0 & 1193 & 61.0 & 1145 & 64.0 & 1248 & 883 \\
\hline $\operatorname{Ash}^{\prime}$ & 8.8 & & 7.5 & & 9.1 & & \\
\hline$C P^{1}$ & 20.2 & 240 & 10.7 & 123 & 21.1 & 262 & 188 \\
\hline $\mathrm{NDF}^{1}$ & 51.4 & 601 & 60.8 & 694 & 48.5 & 605 & 428 \\
\hline Cellulose $^{1}$ & 33.2 & 389 & 31.9 & 363 & 25.0 & 312 & 221 \\
\hline Hemicellulose & 18.1 & 92 & 25.4 & 292 & 21.9 & 273 & 193 \\
\hline Lignin' & 10.1 & 120 & 3.5 & 39 & 1.6 & 20 & 14 \\
\hline Digestibility & 55.6 & & 66.0 & & 76.6 & & \\
\hline
\end{tabular}


ensiling at an earlier stage, also resulting in a higher CP and a lower NDF content. The composition of the cell wall fraction of the alfalfa silage differed significantly from the composition of the cell wall fraction in both grass silages. In the grass silages, the relative proportions of cellulose, hemicellulose and lignin differed slightly; for $\mathrm{G} 1$ and $\mathrm{G} 2,52.2,41.6,5.7$ and 51.5, 45.2, 3.3, respectively. For the alfalfa silage these figures were $64.6,15.8,19.6$. In Exp. I, the intake of the alfalfa silage was slightly higher than the intake of the grass silage, despite a considerably lower digestibility. The NDF intake however was highest for G1. In Exp. II, dry matter intake for $\mathrm{G} 2 \mathrm{H}$ was higher than the intake of both silages in Exp. I. The NDF intake however was about comparable to that for the alfalfa silage.

The VFA concentrations of the rumen fluid are given in Table 2. In Exp. I, the ratio non-glucogenic to glucogenic VFA (NGR) was higher for the grass silage (G1) than for the alfalfa silage. In Exp. II, NGR showed no difference between intake levels, but was slightly but significantly $(P<0.05)$ lower than for G1, probably because of the higher digestibility of G2. There were only slight differences in total VFA concentrations. The protein breakdown products iso volatile fatty acids could only be detected after feeding $A$ and $G 2$.

Table 3 shows the digestibilities of the cell wall constituents. The cell wall fraction of A showed the lowest digestibility. In both silages of Exp. I, cellulose was better digested than hemicellulose. The difference in digestibility of both fractions was highest for $A$. In the highly digestible silage $G 2$, digestibilities of these cell wall fractions hardly differed. Partial digestion in the rumen was the same within the grass silages. For A, partial digestion in the rumen tended to be lower, though not significantly.

The fractional rates of marker decline, volume of rumen liquids and the flow of

Table 2. Concentration ( $\mathrm{mmol} / \mathrm{l}$ ) of volatile fatty acids and ammonia (NH3), the ratio of non-glucogenic to glucogenic VFA (NGR) and $\mathrm{pH}$ in rumen fluid.

\begin{tabular}{|c|c|c|c|c|c|c|}
\hline \multirow[t]{2}{*}{ Acid } & \multicolumn{3}{|c|}{ Exp. I } & \multicolumn{3}{|c|}{ Exp. II } \\
\hline & $\bar{A}$ & G1 & SEM & $\overline{\mathrm{G} 2 \mathrm{H}}$ & G2L & SEM \\
\hline Acetic & 61.9 & 66.0 & $1.22^{*}$ & 68.3 & 67.3 & 2.54 \\
\hline Propionic & 17.2 & 16.8 & 0.76 & 18.8 & 17.9 & 0.53 \\
\hline Isobutyric & 1.06 & - & - & 1.13 & 0.95 & 0.13 \\
\hline Butyric & 5.47 & 6.82 & $0.33^{*}$ & 8.02 & 7.09 & 0.47 \\
\hline Isovaleric & 1.37 & - & - & - & - & - \\
\hline Valeric & 1.56 & 0.66 & $0.09^{* * *}$ & 1.95 & 1.40 & $0.12^{* *}$ \\
\hline NGR & 3.91 & 4.76 & $0.18^{* *}$ & 4.08 & 4.18 & 0.15 \\
\hline $\mathrm{NH}^{1}{ }^{1}$ & 16.6 & 6.1 & $0.85^{* * *}$ & 18.4 & 17.0 & 1.25 \\
\hline $\mathrm{pH}^{\mathrm{l}}$ & 6.75 & 6.48 & $0.02^{* * *}$ & 6.56 & 6.59 & 0.01 \\
\hline
\end{tabular}

I Mean of $1,2,3$ and $4(0)$ h after feeding.

- Not detected.

* $P<0.05 ;{ }^{*} P<0.01 ; * * * P<0.001$. 
M. W. BOSCH, I. M. JANSSEN, J. VAN BRUCHEM, H. BOER AND G. HOF

Table 3. Overall and partial (rumen) digestibility (\%) of cell wall constituents.

\begin{tabular}{llllll} 
Exp. I & & \multicolumn{3}{l}{} & Exp. II \\
A & G1 & SEM & G2H & G2L & SEM
\end{tabular}

Overall

\begin{tabular}{lcccccc} 
NDF & 44.4 & 68.8 & $1.8^{* * *}$ & 81.2 & 81.1 & 0.9 \\
Cellulose & 57.7 & 75.9 & $1.1^{* * *}$ & 86.8 & 85.5 & 1.0 \\
Hemicellulose & 28.2 & 69.2 & $2.6^{* * *}$ & 82.7 & 84.2 & 1.3 \\
Lignin & 13.4 & 10.8 & 2.1 & 0 & 0 & 0 \\
Partial & & & & & & \\
NDF & 82.5 & 90.6 & 5.1 & 89.2 & 89.1 & 0.8 \\
Cellulose & 86.8 & 87.8 & 3.6 & 92.3 & 93.1 & 1.6 \\
Hemicellulose & 69.7 & 88.8 & 12.9 & 86.9 & 85.8 & 1.0 \\
Lignin & 0 & 0 & 0 & 0 & 0 & 0 \\
\hline
\end{tabular}

${ }^{* * *} P<0.001$.

rumen liquids and cell wall constituents are presented in Table 4 . The $k_{1, \mathrm{r}}$ measured directly in rumen fluid was significantly $(P<0.001)$ higher for $\mathrm{G} 1$ than for $\mathrm{A}$ and also higher $(P<0.001)$ for $\mathrm{G} 2 \mathrm{H}$ than for $\mathrm{G} 2 \mathrm{~L}$. The $k_{1}$ values, as derived from the faecal excretion curves showed comparable differences, although mean level of these $k$ values was lower than measured in the rumen fluid, and differences were less significant. The ratio between $k_{\mathrm{p}}$ and $k_{1}$ (measured in the faeces) declined in proportion to the intake of indigestible dry matter in the following order: $0.82(\mathrm{~A})$, $0.67(\mathrm{G} 1), 0.57(\mathrm{G} 2 \mathrm{H}), 0.53(\mathrm{G} 2 \mathrm{~L})$. Rumen motility was related neither to the flow of liquids nor to the flow of cell wall particles from the rumen. Within the grass silages, motility was related negatively to digestibility, but hardly affected by level of dry matter intake.

The rate of degradation, as determined for the silages of Exp. I with nylon bags in cattle, is presented in Table 5. Fractional rates of degradation of the cell wall fraction were comparable. The non-degradable fraction however was significantly higher for the alfalfa silage.

The organic matter (OM) pool in the reticulorumen can be related to OM passage in the proximal duodenum $\left(\mathrm{OM}_{\mathrm{p}}\right)$ according to the following model:

$$
\mathrm{OM}=\frac{\mathrm{OM}_{\mathrm{p}}}{\left(1-f_{\mathrm{L}}\right) \times k_{\mathrm{p}}}
$$

with $f_{\mathrm{L}}$ representing the large particle pool as a fraction of the total particle pool, and $k_{\mathrm{p}}$ the fractional rate of emptying of small particles from the reticulorumen. Based on volume of rumen liquids, as presented in Table 4, content of OM in rumen digesta could be related to $f_{\mathrm{L}}$ as demonstrated in Fig. 1. Accepting a range in OM content in the rumen of $8-12 \%$, possible $f_{\mathrm{L}}$ values can be estimated per silage. As- 
Table 4. Fractional passage rates of the liquid $\left(k_{1, r}\right.$ and $\left.k_{1}\right)$ and particulate $\left(k_{\mathrm{p}}\right)$ phases in the rumen, as measured in the rumen and as derived from the marker excretion curves in the faeces, volume of rumen liquids, flow of liquid and cell walls (NDF) from the rumen and frequency of rumen motility $(n=16)$.

\begin{tabular}{|c|c|c|c|c|c|c|}
\hline & Exp. I & & & Exp. II & & \\
\hline & A & Gl & SEM & $\mathrm{G} 2 \mathrm{H}$ & G2L & SEM \\
\hline Rumen volume (1) & 9.5 & 9.8 & 0.15 & 7.6 & 7.1 & 0.45 \\
\hline $\begin{array}{l}\left.k_{1, r} \text { (rumen, } \% / \mathrm{h}\right) \\
\text { Flow of }\end{array}$ & 7.4 & 8.4 & $0.14^{* * *}$ & 8.1 & 6.7 & $0.19^{* * *}$ \\
\hline Fluid $(\mathrm{ml} / \mathrm{h})$ & 700 & 815 & $21.0^{* *}$ & 604 & 450 & $23.6^{* *}$ \\
\hline $\operatorname{NDF}(g / h)^{1}$ & 15.8 & 11.0 & $0.44^{* * *}$ & 6.7 & 5.0 & $0.22 * * *$ \\
\hline$k_{1}($ faeces, $\% / \mathrm{h})$ & 4.9 & 5.7 & $0.14^{* *}$ & 4.9 & 3.8 & $0.29^{*}$ \\
\hline$k_{\mathrm{p}}($ faeces, $\% / \mathrm{h})$ & 4.0 & 3.8 & 0.13 & 2.8 & 2.0 & $0.12^{* *}$ \\
\hline $\begin{array}{l}\text { Rumen motility } \\
\text { (contr./day) }\end{array}$ & 2433 & 3051 & $91.0^{* * *}$ & 2538 & 2425 & 52.0 \\
\hline
\end{tabular}

${ }^{1} \mathrm{NDF}(\mathrm{g} / \mathrm{h})$ derived from the quantities of NDF passing the small intestine

${ }^{*} P<0.05 ;{ }^{* *} P<0.01 ;{ }^{* * *} P<0.001$.

suming a content of cell walls in rumen organic matter close to that in the proximal duodenum, the reticuloruminal cell wall pool can be estimated as well.

The fraction of cell walls leaving the reticulorumen undegraded $\left(f_{\mathrm{U}}\right)$ can be approached with the following model:

$$
f_{\mathrm{U}}=f_{\mathrm{R}}+\left(1-f_{\mathrm{R}}\right) \times \frac{\left(1-f_{\mathrm{L}}\right) \times k_{\mathrm{p}}}{\left(1-f_{\mathrm{L}}\right) \times k_{\mathrm{p}}+k_{\mathrm{d}}}
$$

with $f_{\mathrm{R}}$ and $k_{\mathrm{d}}$ as in (2), and $f_{\mathrm{L}}$ and $k_{\mathrm{p}}$ as in (3).

Ranges of $k_{\mathrm{d}}$ values, as based on $f_{\mathrm{L}}$ values obtained from Fig. 1, are presented in Table 5 . It seems that with the less digestible silages $\mathrm{A}$ and $\mathrm{G} 1, f_{\mathrm{L}}$ was considerably higher than with $\mathrm{G} 2$. Substitution in (4) delivered $k_{\mathrm{d}}$ ranges for G2 higher than those with $\mathrm{A}$ and $\mathrm{G} 1$.

Table 5 . The fraction of cell walls ingested leaving the reticulorumen $\left(f_{\mathrm{L}}, \%\right)$ as determined by silage indigestible cell wall fraction $\left(f_{\mathrm{R}}, \%\right)$, fractional rate of passage of particles from the rumen $\left(k_{\mathrm{p}} . \% / \mathrm{h}\right)$ and the relative proportion of large particles $\left(f_{\mathrm{L}}, \%\right)$ with the fractional rate of digestion $\left(k_{\mathrm{L}}, \% / \mathrm{h}\right)$, as determined by nylon bags or computed.

\begin{tabular}{|c|c|c|c|c|c|c|}
\hline & $f_{\mathrm{U}}$ & $f_{\mathrm{R}}$ & $k_{\mathrm{p}}$ & $f_{\mathrm{L}}{ }^{1}$ & $k_{\mathrm{d}}{ }^{2}$ & $k_{\mathrm{d}}{ }^{3}$ \\
\hline A & 63.5 & $52.1^{\mathrm{l}}$ & 4.0 & $27-54$ & $5.9-9.4$ & 4.0 \\
\hline $\mathrm{G} 1$ & 38.0 & $20.4^{1}$ & 3.8 & $33-58$ & $5.6-9.0$ & 4.3 \\
\hline $\mathrm{G} 2 \mathrm{H}$ & 27.6 & 15 & 2.8 & $0-32$ & $10.9-16.1$ & \\
\hline $\mathrm{G} 2 \mathrm{~L}$ & 27.7 & 15 & 2.0 & $0-27$ & $8.3-11.4$ & \\
\hline
\end{tabular}

\footnotetext{
Derived from Fig. 1.

2 According to (4).

${ }^{3}$ Kwakkel et al. (1986).
} 


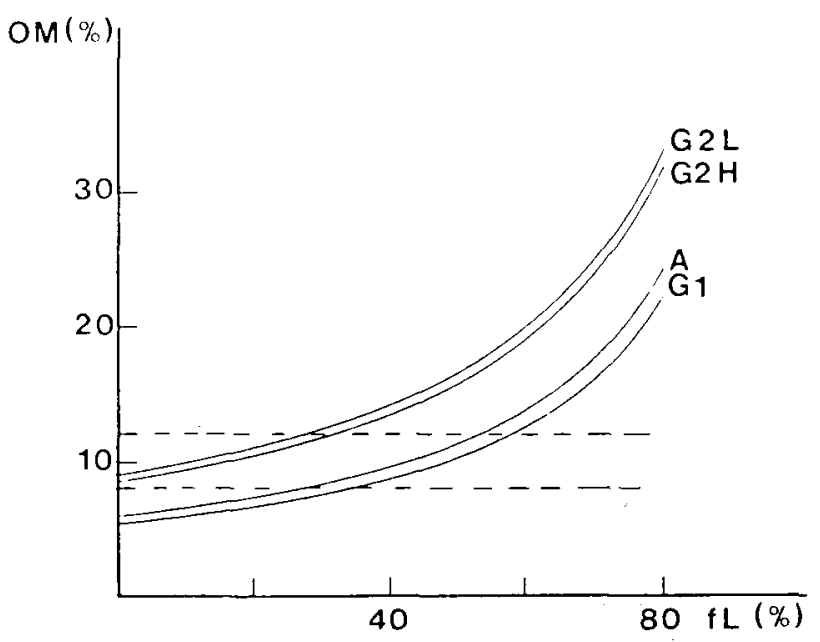

Fig. 1. Organic matter $(\mathrm{OM}, \%)$ in rumen digesta as related to the large particle pool, expressed as a fraction $\left(f_{\mathrm{L}}\right)$ of the total particle pool.

\section{Discussion}

Although differences in digestibility of the silages fed in the present experiments were considerable, VFA concentrations and the ratio in which VFA's were produced (NGR) were affected only slightly. Average rumen pH did not show consistent differences between diets either. Rumen $\mathrm{pH}$ was kept at a level favourable for degradation of cell wall constituents by cellulolytic microbes. Despite the high digestibility of the $\mathrm{G} 2$ silage, rate of digestion was probably lower in comparison with mixed concentrates, thus not inducing a shift in $\mathrm{pH}$.

Intake of the alfalfa silage was slightly higher compared to the G1 grass silage, despite a considerably lower digestibility. Within grass silages, however, intake was positively related to digestibility.

Fractional rates of passage of particles as measured with $\mathrm{Cr}-\mathrm{NDF}$, did not differ between the silages of Exp. I. However, fractional rate of particle passage of the better digestible G2 silage was significantly lower than with $A$ and $G 1$ silages. The fractional rate of passage of the fluid phase was higher for $\mathrm{G} 1$ than for $\mathrm{A}$. For $\mathrm{G} 2, k_{1}$ was significantly lower than for $\mathrm{G} 1$ at both levels of feed intake. Fractional rate of passage of rumen liquid is presumably primarily determined by rumination activity. For the G2 silage with the higher digestibility, rumination per kg of dry matter ingested may be supposed to be lowest, here resulting in a smaller volume of rumen liquids as well as a lower fractional flow of liquids leaving the rumen.

Contrary to this, rumen motility showed no relationship to level of intake of the G2 silage, despite significant $(P<0.001)$ differences in $k_{1}$, as measured directly in the rumen, and $k_{\mathrm{p}}$. Frequency of rumen motility differed highly significantly $(P<$ 
0.001 ) between $\mathrm{A}$ and $\mathrm{G} 1$ silages, coinciding in a comparable difference in $k_{1}$ but not in $k_{\mathrm{p}}$. Thus the conclusion has to be drawn that motility did not show any consistent relationship to fractional passage of the liquid and particulate phases from the reticulorumen. Probably other factors are involved such as rumen fill, stimulation of receptors in the rumen wall by feed particles and resistance of particles to leave the rumen particulate matrix.

In comparison with liquids, the sequence of processes for the particulate fraction is much more complex. Feed particles have to be degraded especially physically before they can leave the reticulorumen. Chewing during ingestion of feed primarily causes desintegration of cell wall structures, essential for enabling rumen microbes to effectively invade the inner structures of the feed particles. Subsequent degradation to particles smaller than $1 \mathrm{~mm}$ is realized by rumination. Chai et al. (1984) found that rumination time per $\mathrm{kg}$ dry matter intake was higher for brome grass than for alfalfa. Also in the present experiments, both eating and rumination time seemed to be less for the A silage, as compared to the G1 silage. Thus despite a lower digestibility, alfalfa silage seems physically easier degradable than G1 silage. The fractional rate of passage of undigested feed particles from the rumen, as measured with $\mathrm{Cr}-\mathrm{NDF}$, did not differ significantly. Cr-NDF, however, may within certain limits only be regarded as representing the small particle pool in the rumen, but not particles sized larger than $1 \mathrm{~mm}$. Since passage rate of cell walls from the rumen was higher for A silage in comparison with G1 silage, the so-called small particle pool was presumably biggest for the A silage. Since alfalfa feed particles are physically more easily degraded, the ratio larger to smaller particle pool may be expected to be slightly lower for the A silage than for the G1 silage. This difference was not significant, however, as could be deduced from Fig. 1.

Possibly because of its structure alfalfa particles are easier to reduce in size than ryegrass or brome grass particles (Lee \& Pearce, 1984; Chai et al. 1984). In part this might be attributable to the way the different components are mutually integrated in leaves and stems. In comparison with grasses, alfalfa exhibits a greater difference between leaf and stem structures. The older stems of alfalfa are highly lignified, whereas fibre content of leaves remains low. However, Ulyatt et al. (1986) were not able to reveal comparable differences in extent of physical degradation between fresh perennial ryegrass and alfalfa. Unfortunately, details on composition of the diets used were not provided.

In Exp. II, fractional passage rates of both fluid and particulate phases were highest for the higher intake level. Fractional passage rate of the particulate phase for G2H was lower than for the G1 silage of Exp. I, despite the higher digestibility. The negative relation between rate of passage of the particulate phase and digestibility within grass silages, can presumably be explained as follows. With the highly digestible G2 silage, the level of feed intake in these mature wethers, was probably not limited by rumen capacity, but chemostatically by nutrient requirements for maintenance. Thus, fractional passage of undegraded feed particles from the rumen is determined by the possibility of particles to leave the rumen on one hand, and the quantity of undegraded feed particles present in the rumen as the driving force on the other. Based on this approach, rates of passage of undegraded feed particles are 
expected to increase with quantity of undigestible material ingested, provided particle size has been reduced.

Within grass silages, increasing digestibility will result in an increased rate of reduction of larger particles. Thus with highly digestible diets, the ratio larger to smaller particles is supposed to decrease, ultimately resulting in smaller particles being predominant. Then a high rate of passage is only to be expected with high levels of feed intake, as induced by nutrient requirements consistently higher than maintenance level. At lower levels of nutrient requirements, feed intake is submaximal with respect to rumen capacity and as a consequence $k_{\mathrm{p}}$ is low. Within grass silages a lower digestibility caused $k_{1}$ to increase due to time spent ruminating, but the increase in $k_{\mathrm{p}}$ was even more significant, resulting in an increased ratio $k_{\mathrm{p}}: k_{\mathrm{l}}$.

The digestibility of the NDF fraction of A was significantly lower than of the G1 silage, primarily caused by the difference in the undigestible fraction $f_{\mathrm{U}}$. For $\mathrm{G} 2$ the rate of degradation $\left(k_{\mathrm{d}}\right)$ of the NDF fraction was not determined, but may be expected to be higher than for $A$ and $G 1$. The fraction of the cell wall constituents not digested in the rumen and thus entering the small intestine $\left(f_{U}=\right.$ undigested fraction), consists for the larger part of a non-degradable fraction $\left(f_{\mathrm{R}}\right)$ and a fraction which is potentially degradable, but escaped rumen fermentation.

For the A silage, $63.5 \%$ of the NDF fraction entered undegraded the small intestine. The $k_{\mathrm{p}}$, as determined with $\mathrm{Cr}-\mathrm{NDF}$, was $4.0 \% / \mathrm{h}$ and $f_{\mathrm{R}}$, as determined with nylon bags, $52.1 \%$. Substituting these values in (4), with $f_{\mathrm{L}}=0$, would give a $k_{\mathrm{d}}$ of $12.8 \%$. This $k_{\mathrm{d}}$, however, should be regarded as an overestimation of the actual value. The $k_{\mathrm{p}}$, as determined with $\mathrm{Cr}-\mathrm{NDF}$, however, does not represent the total cell wall pool in the rumen. Waghorn et al. (1986) fed chaffed alfalfa hay to 32 sheep. Particle size distributions from the rumen, obtained at slaughter showed that $40 \%$ of the rumen content consisted of particles retained on the $1 \mathrm{~mm}$ sieve. Assuming in the present experiment a comparable $f_{\mathrm{L}}$, with the A silage Cr-NDF representing the particles smaller than $1 \mathrm{~mm}$, would only represent $60 \%$ of the rumen cell wall pool, resulting with (4) in a $k_{\mathrm{d}}$ of $7.7 \%$. The acceptable range of $k_{\mathrm{d}}$, based on $f_{\mathrm{L}}$ values derived from Fig. 1 , is presented in Table 5. Ulyatt et al. (1986) reported that the $k_{\mathrm{d}}$ for fresh chewed ryegrass was consistently higher than for fresh unchewed ryegrass, both determined in nylon bags. The difference between the $k_{\mathrm{d}}$ determined by Kwakkel et al. (1986) of $4.0 \% / \mathrm{h}$ and the $k_{\mathrm{d}}$ range calculated here of $5.9-9.4 \% / \mathrm{h}$ is probably mainly caused by the difference between chewed and unchewed material and for the other part by difference in particle size. Kwakkel et al. (1986) introduced particles of up to $5 \mathrm{~mm}$ into the nylon bags. With the same approach, a $k_{\mathrm{d}}$ range for $\mathrm{G} 1$ could be computed, more or less comparable to A.

Rumination time per kg dry matter has been shown to be higher for restricted intake levels than for ad lib levels (Bae et al., 1981). This was confirmed in the present experiments. For G2H and G2L, rumination time was 6.6 and $8.2 \mathrm{~h}$ per kg dry matter, respectively. As a result a proportionally larger fraction of particles smaller than $1 \mathrm{~mm}$ for G2L should be expected. Substituting in (4) for $\mathrm{G} 2 \mathrm{H} f_{\mathrm{U}}=27.6 \%$ and an assumed value for $f_{\mathrm{R}}$ of $15 \%$, with a proportion of larger particles of up to $32 \%$, a $k_{\mathrm{d}}$ range of $10.9-16.1 \% / \mathrm{h}$ was computed, probably to be regarded as an overestimation. For G2L, a proportion larger particles of up to $27 \%$ was found 
(Fig. 1), resulting in a more reliable $k_{\mathrm{d}}$ range of $8.3-11.4 \% / \mathrm{h}$. An overview of the parameters obtained with the model presented in (4) has been given in Table 5. In order to enable us to verify whether these calculations are correct, in experiments in progress with dairy cattle, in the rumen both pool sizes of cell wall constituents and of particles, based on sieve analysis are determined as well.

\section{Acknowledgements}

The authors gratefully acknowledge Ing. L.A. Mol of the LU Department of Field Crops and Grassland Science and $\mathrm{Mr} \mathrm{H}$. van Dijk of the LU research facility 'De Ossekampen' for growing and ensiling the roughages, Messrs G.A. Bangma and G. van Gelderen for taking care of the cannulated animals and conducting the experiments, Mrs S.C.W. Lammers-Wienhoven, Miss T. Post, Miss J.M. Muylaert, and Messrs W. Onck and C.P. Leffering for skilled analytical assistance and $\mathrm{Mr} \mathrm{W}$. Bijlsma for developing the pressure transducer. In addition we thank Mr R. Bremmers and Messers A. Claassen, A.K. Kies and J.D. van der Klis, who contributed as undergraduate students to this research program.

\section{References}

Anonymous, 1983. BMDP Statistical Software, University of California Press, USA

Bae, D. H., J. G. Welch \& A. M. Smith, 1981. Efficiency of mastication in relation to hay intake by cattle. Journal of Animal Science 52: 1371-1375.

Binnerts, W. T., A. Th. van 't Klooster \& A. M. Frens, 1968. Soluble chromium indicator measured by atomic absorption in digestion experiments. Veterinary Record 82: 470.

Bruchem, J. van, A. K. Kies, R. Bremmers, M. Bosch, H. Boer \& P. W. M. van Adrichem. 1988. Digestion of alfalfa and grass silages in sheep. 2. Digestion of protein in reticulorumen and intestines. Netherlands Journal of Agricultural Science (submitted).

Chai, K., P. M. Kennedy \& L. P. Milligan, 1984. Reduction in particle size during rumination in cattle. Canadian Journal of Animal Science 64 (Suppl.): 339-340.

Goering, H. K. \& P. J. van Soest, 1970. Forage fiber analyses. Agricultural Handbook No 379. ARS, USDA, Washington. DC. USA.

Grovum, W. L. \& V. J. Williams, 1973. Rate of passage of digesta in sheep. 4. Passage of marker through the alimentary tract and the biological relevance of rate constants derived from the changes in concentration of marker in faeces. British Journal of Nutrition 30: 313-329.

Kwakkel R. P., J. van Bruchem, G. Hof \& H. Boer, 1986. The in sacco degradation of crude protein and cell wall constituents in grass, alfalfa and maize silages. Netherlands Journal of Agricultural Science 34: $116-119$.

Lee, J. A. \& G. R. Pearce, 1984. The effectiveness of chewing during eating on particle reduction of roughages by cattle. Australian Journal of Agricultural Research 35: 609-618.

Uden, P., P. E. Colluci \& P. J. van Soest, 1980. Investigation of chromium, cerium and cobalt as markers in digesta. Journal of Science in Food and Agriculture 31: 625-632.

Ulyatt, M. J., D. W. Dellow, A. John, C. S. W. Reid \& G. C. Waghorn, 1986. Contribution of chewing during eating and rumination to clearance of digesta from the reticulorumen. In: L. P. Milligan, W. L. Grovum \& A. Dobson (Eds), Control of digestion and metabolism in ruminants, p. 498-515. Englewood Cliffs, Prentice-Hall.

Waghorn, G. C., C. S. W. Reid, M. J. Ulyatt \& A. John, 1985. Feed comminution, particle composition and distribution between the four compartments of the stomach in sheep fed chaffed lucerne hay at two feeding frequencies and intake levels. Journal of Agricultural Science 106: 287-296. 